\section{TRENDS IN INTERNATIONAL ARMS TRANSFERS, 2020}

PIETER D. WEZEMAN, ALEXANDRA KUIMOVA AND

SIEMON T. WEZEMAN

The volume of international transfers of major arms in 2016-20 was 0.5 per cent lower than in 2011-15 and 12 per cent higher than in 2006-10 (see figure 1). ${ }^{1}$ The five largest arms exporters in 2016-20 were the United States, Russia, France, Germany and China (see table 1). The five largest arms importers were Saudi Arabia, India, Egypt, Australia and China (see table 2). Between 2011-15 and 2016-20 there were increases in arms transfers to the Middle East ( 25 per cent) and to Europe (12 per cent), while there were decreases in the transfers to Africa ( -13 per cent), the Americas ( -43 per cent), and Asia and Oceania ( -8.3 per cent).

From 15 March 2021 SIPRI's open-access Arms Transfers Database includes updated data on transfers of major arms for 1950-2020, which replaces all previous data on arms transfers published by SIPRI. Based on the new data, this Fact Sheet presents global trends in arms exports and arms imports, and highlights selected issues related to transfers of major arms (see box 1).

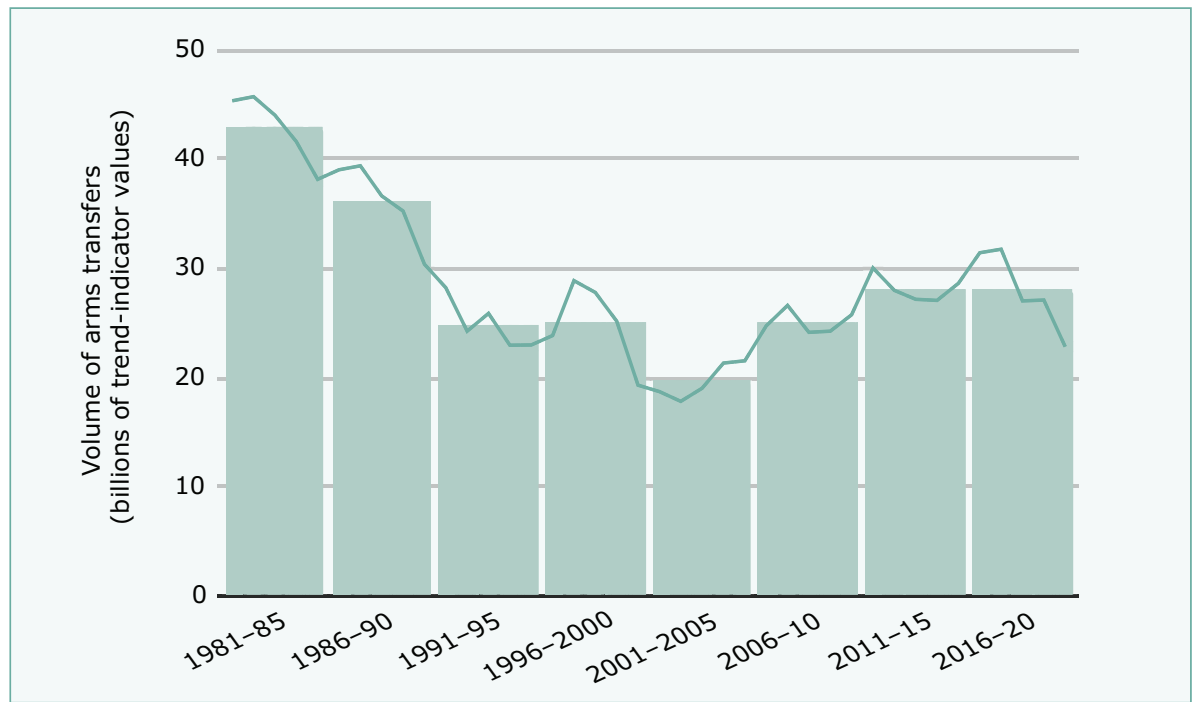

Figure 1. The trend in international transfers of major arms, 1981-2020

Note: The bar graph shows the average volume of arms transfers for 5 -year periods and the line graph shows the annual totals. The SIPRI trend-indicator value (TIV) is a measure of the volume of international transfers of major arms. The method used for the SIPRI TIV is described on the Arms Transfers Database web page.

Source: SIPRI Arms Transfers Database, Mar. 2021.

\footnotetext{
${ }^{1}$ In this Fact Sheet the terms 'arms exports' and 'arms imports' are used to refer to international transfers of major arms, as defined by SIPRI.
}

\section{KEY FACTS}

- The volume of international transfers of major arms in 2016-20 was 0.5 per cent lower than in 2011-15 and 12 per cent higher than in 2006-10.

- The five largest arms exporters in 2016-20 were the United States, Russia, France, Germany and China. Together, they accounted for 76 per cent of all exports of major arms in 2016-20.

- In 2016-20 US arms exports accounted for 37 per cent of the global total and were 15 per cent higher than in 2011-15.

- Russian arms exports decreased by 22 per cent between 2011-15 and 2016-20.

- Between 2011-15 and 2016-20 arms exports by France and Germany increased by 44 and 21 per cent, respectively, whereas those of China decreased by 7.8 per cent.

- The five largest arms importers in 2016-20, Saudi Arabia, India, Egypt, Australia and China, together received 36 per cent of all imports of major arms.

- The main recipient region in 2016-20 was Asia and Oceania (accounting for 42 per cent of global arms imports), followed by the Middle East (33 per cent), Europe (12 per cent), Africa (7.3 per cent) and the Americas (5.4 per cent). 
Table 1. The 25 largest exporters of major arms and their main recipients, 2016-20

Note: Percentages below 10 are rounded to 1 decimal place; percentages over 10 are rounded to whole numbers.

\begin{tabular}{|c|c|c|c|c|c|c|c|}
\hline & \multirow[b]{2}{*}{ Exporter } & \multicolumn{2}{|c|}{$\begin{array}{l}\text { Share of } \\
\text { arms exports (\%) }\end{array}$} & \multirow{2}{*}{$\begin{array}{l}\text { Per cent } \\
\text { change from } \\
2011-15 \text { to } \\
2016-20^{a}\end{array}$} & \multicolumn{3}{|c|}{$\begin{array}{l}\text { Main recipients (share of exporter's total exports, \%), } \\
2016-20\end{array}$} \\
\hline & & $2016-20$ & 2011-15 & & 1 st & 2nd & $3 r d$ \\
\hline 1 & United States & 37 & 32 & 15 & Saudi Arabia (24) & Australia (9.4) & South Korea (6.7) \\
\hline 2 & Russia & 20 & 26 & -22 & India (23) & China (18) & Algeria (15) \\
\hline 3 & France & 8.2 & 5.6 & 44 & India (21) & Egypt (20) & Qatar (18) \\
\hline 4 & Germany & 5.5 & 4.5 & 21 & South Korea (24) & Algeria (10) & Egypt (8.7) \\
\hline 5 & China & 5.2 & 5.6 & -7.8 & Pakistan (38) & Bangladesh (17) & Algeria (8.2) \\
\hline 6 & United Kingdom & 3.3 & 4.6 & -27 & Saudi Arabia (32) & Oman (17) & USA (14) \\
\hline 7 & Spain & 3.2 & 3.5 & -8.4 & Australia (33) & Singapore (13) & Turkey (9.7) \\
\hline 8 & Israel & 3.0 & 1.9 & 59 & India (43) & Azerbaijan (17) & Viet Nam (12) \\
\hline 9 & South Korea & 2.7 & 0.9 & 210 & UK (14) & Philippines (12) & Thailand (11) \\
\hline 10 & Italy & 2.2 & 2.8 & -22 & Turkey (18) & Egypt (17) & Pakistan (7.2) \\
\hline 11 & Netherlands & 1.9 & 2.0 & -6.1 & Indonesia (17) & USA (15) & Mexico (10) \\
\hline 12 & Ukraine & 0.9 & 2.6 & -68 & China (36) & Russia $(20)^{b}$ & Thailand (17) \\
\hline 13 & Turkey & 0.7 & 0.6 & 30 & Oman (19) & Turkmenistan (19) & Malaysia (11) \\
\hline 14 & Switzerland & 0.7 & 1.1 & -35 & Australia (23) & China (13) & Denmark (8.0) \\
\hline 15 & Sweden & 0.7 & 1.5 & -54 & USA (25) & Pakistan (11) & Algeria (11) \\
\hline 16 & Australia & 0.5 & 0.3 & 81 & Chile (31) & USA (27) & Canada (20) \\
\hline 17 & Canada & 0.5 & 0.9 & -45 & Saudi Arabia (49) & UAE (17) & Australia (5.0) \\
\hline 18 & UAE & 0.5 & 0.3 & 68 & Egypt (34) & Jordan (21) & Algeria (14) \\
\hline 19 & Belarus & 0.3 & 0.5 & -34 & Viet Nam (26) & Serbia (16) & Sudan (13) \\
\hline 20 & Brazil & 0.3 & 0.1 & 147 & Afghanistan (26) & France (21) & Chile (10) \\
\hline 21 & Norway & 0.3 & 0.6 & -50 & Oman (47) & USA (17) & Poland (13) \\
\hline 22 & South Africa & 0.3 & 0.3 & -16 & USA (24) & UAE (17) & India (13) \\
\hline 23 & Czechia & 0.3 & 0.2 & 56 & Iraq (29) & USA (22) & Ukraine (14) \\
\hline 24 & India & 0.2 & 0.1 & 228 & Myanmar (52) & Sri Lanka (24) & Mauritius (13) \\
\hline 25 & Portugal & 0.2 & $<0.05$ & 1020 & Romania (98) & Cabo Verde (1.1) & Colombia (1.1) \\
\hline
\end{tabular}

UAE = United Arab Emirates.

${ }^{a}$ Figures show the change in volume of the total arms exports per exporter between the 2 periods.

${ }^{b}$ This involved transport aircraft produced in Russia until 2018 under licences granted before Ukraine banned arms sales to Russia in 2014.

Source: SIPRI Arms Transfers Database, Mar. 2021.

\section{THE EXPORTERS, 2016-20}

SIPRI has identified 65 states as exporters of major arms in 2016-20. The five largest suppliers of arms during that period-the USA, Russia, France, Germany and China-accounted for 76 per cent of all arms exports (see figure 2 and table 1). France had the highest increase in arms exports among the top five. US and German arms exports also grew, while Russian and Chinese arms exports decreased (see figure 3). The top 25 arms exporters accounted for 99 per cent of global exports of major arms in 2016-20 (see table 1). States in North America and Europe together accounted for 86 per cent of all arms exports.

\section{The United States}

US arms exports grew by 15 per cent between 2011-15 and 2016-20, increasing its global share from 32 to 37 per cent. The USA delivered major arms to 
96 states in 2016-20, a far higher number of recipients than any other supplier. In 2016-20 total arms exports by the USA were 85 per cent higher than those of Russia-the second largest exporter-compared with 24 per cent higher in 2011-15.

Almost half (47 per cent) of US arms exports went to the Middle East in 2016-20, an increase of 28 per cent on the previous five-year period. There were particularly large increases in US arms exports to three countries in the region between 2011-15 and 2016-20: Israel (335 per cent), Qatar (208 per cent) and Saudi Arabia (175 per cent). Saudi Arabia was the main recipient of US arms transfers in 2016-20, accounting for 24 per cent of US arms exports.

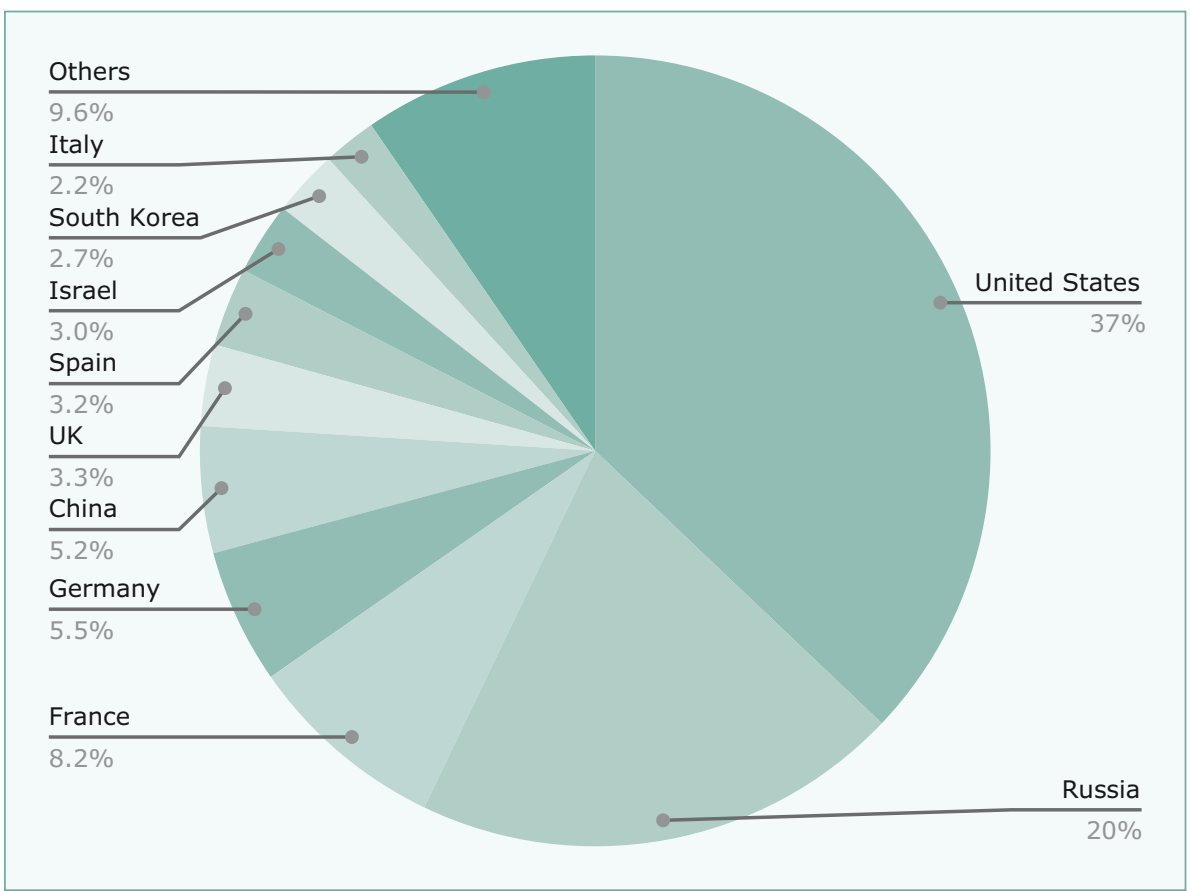

Figure 2. Global share of major arms exports by the 10 largest exporters, 2016-20

Source: SIPRI Arms Transfers Database, Mar. 2021.

Qatar and Israel were the sixth

and seventh largest importers of US arms respectively.

There were notable decreases in US arms exports to the United Arab Emirates (UAE) and to Turkey between 2011-15 and 2016-20. US arms exports to the UAE fell by 36 per cent, making it the fifth largest recipient of US arms in 2016-20. The 81 per cent decrease in US arms transfers to Turkey meant that it dropped from being the 3 rd largest recipient of US arms exports in 2011-15 to the 19th largest in 2016-20. In 2019 the USA halted deliveries of combat aircraft to Turkey after Turkey imported air defence systems from Russia. Had the USA not suspended the contract, the fall in US arms exports to Turkey would not have been as steep.

States in Asia and Oceania received 32 per cent of total US arms exports in 2016-20, compared with 34 per cent in 2011-15. Amid the intensifying rivalry between the USA and China, three US allies in the region were among the five largest importers of US arms in 2016-20: Australia accounted

Box 1. The drop in arms transfers in 2020

Significant year-on-year fluctuations in volumes of international transfers of major arms are common. Therefore, SIPRI presents data for five-year periods, giving a more stable measure of trends. However, the value of global arms transfers in 2020 was exceptionally low-16 per cent lower than in 2019 and 20 per cent below the annual average in 2011-19. This might be partly due to the Covid-19 pandemic-which disrupted some arms companies' planned production and delivery schedules-and the related economic crisis. However, the drop in arms transfers in 2020 was also related to other supply- and demand-side factors, including national procurement cycles, gaps in deliveries during shifting relations between suppliers and recipients, and nonpandemic-related economic conditions. The uncertainty about whether the pandemic was a major cause for the fall in arms transfers in 2020 is highlighted, for instance, by the fact that several states actually had higher levels of arms deliveries in 2020 than in some other years in the period 2011-19. For example, US arms exports in 2020 were higher than they were in three years in 2011-19 and French arms exports in 2020 were higher than in five years in the same period. Similarly, on the recipient side, arms deliveries to Australia in 2020 were higher than in any year in 2011-19. 
for 9.4 per cent of US arms exports, South Korea for 6.7 per cent and Japan for 5.7 per cent.

States in Europe received 15 per cent of total US arms exports in 2016-20. This was an increase of 79 per cent on 2011-15, which was mainly due to deliveries of combat aircraft that were ordered in 2006-12. US arms exports to Africa increased by 6.6 per cent between $2011-15$ and 2016-20, while those to the Americas decreased by 48 per cent.

\section{Russia}

In 2016-20 Russia delivered major arms to 45 states and accounted for 20 per cent of total global arms exports. India remained the main recipient of Russian arms in 2016-20, accounting for 23 per cent of the total, followed by China (18 per cent) and Algeria (15 per cent).

Russian arms exports in 2016-20 were at a similar level to 2001-2005 and 2006-10 but were 22 per cent lower than in 2011-15, when Russian arms exports peaked. While Russian arms exports in 2016-18 remained at a relatively high level, they fell in both 2019 and 2020. The overall decrease in Russia's arms exports between 2011-15 and 2016-20 was almost entirely attributable to a 53 per cent drop in its arms exports to India. This decrease was not offset by large increases in Russia's arms exports to China (49 per cent), Algeria (49 per cent) and Egypt (430 per cent). Although several large Russian arms deals with India, including for combat aircraft, were completed by 2020, India placed new orders for a variety of Russian arms in 2019-20. The ensuing deliveries will probably lead to an increase in Russian arms exports in the coming five years.

At the regional level, states in Asia and Oceania accounted for 55 per cent of Russian arms exports in 2016-20, the Middle East for 21 per cent and Africa for 18 per cent. Between 2016-20 and 2011-15 Russian arms exports to Asia and Oceania fell (-36 per cent), while those to the Middle East (64 per cent) and Africa (23 per cent) increased.

Aircraft accounted for 49 per cent of Russian arms exports in 2016-20. These transfers included deliveries of a total of 231 combat aircraft.

\section{The European Union and West European countries}

The combined arms exports of European Union (EU) member states accounted for 26 per cent of the global total in 2016-20, the same percentage as in 2011-15. The top five West European arms exporters-France, Germany, the United Kingdom, Spain and Italy-together accounted for 22 per cent of global arms exports in 2016-20 (see figure 2), compared with 21 per cent in 2011-15.

French arms exports accounted for 8.2 per cent of the global total after increasing by 44 per cent between 2011-15 and 2016-20. At the regional level, the Middle East accounted for 48 per cent of French arms exports in 2016-20 while Asia and Oceania accounted for 36 per cent. Of the 69 states to which France delivered major arms in 2016-20, three-India, Egypt and Qatar-together received 59 per cent of French arms exports (see table 1). Deliveries of aircraft made up 45 per cent of French arms exports in 2016-20, while deliveries of ships accounted for 17 per cent. 
German arms exports represented 5.5 per cent of the global total in 2016-20 and were 21 per cent higher than in 2011-15. Germany delivered major arms to 55 states in 2016-20. A total of 38 per cent of German exports of major arms went to states in Asia and Oceania while 21 per cent went to states in Europe. Although Germany imposed tighter restrictions on arms sales to Saudi Arabia (the biggest arms importer in the Middle East) during 2016-20, the Middle East received 23 per cent of German arms exports in the period, making it the second largest recipient of German arms transfers at the regional level. This was mainly due to the delivery of 3 submarines to Egypt. Deliveries of ships, including 11 submarines,

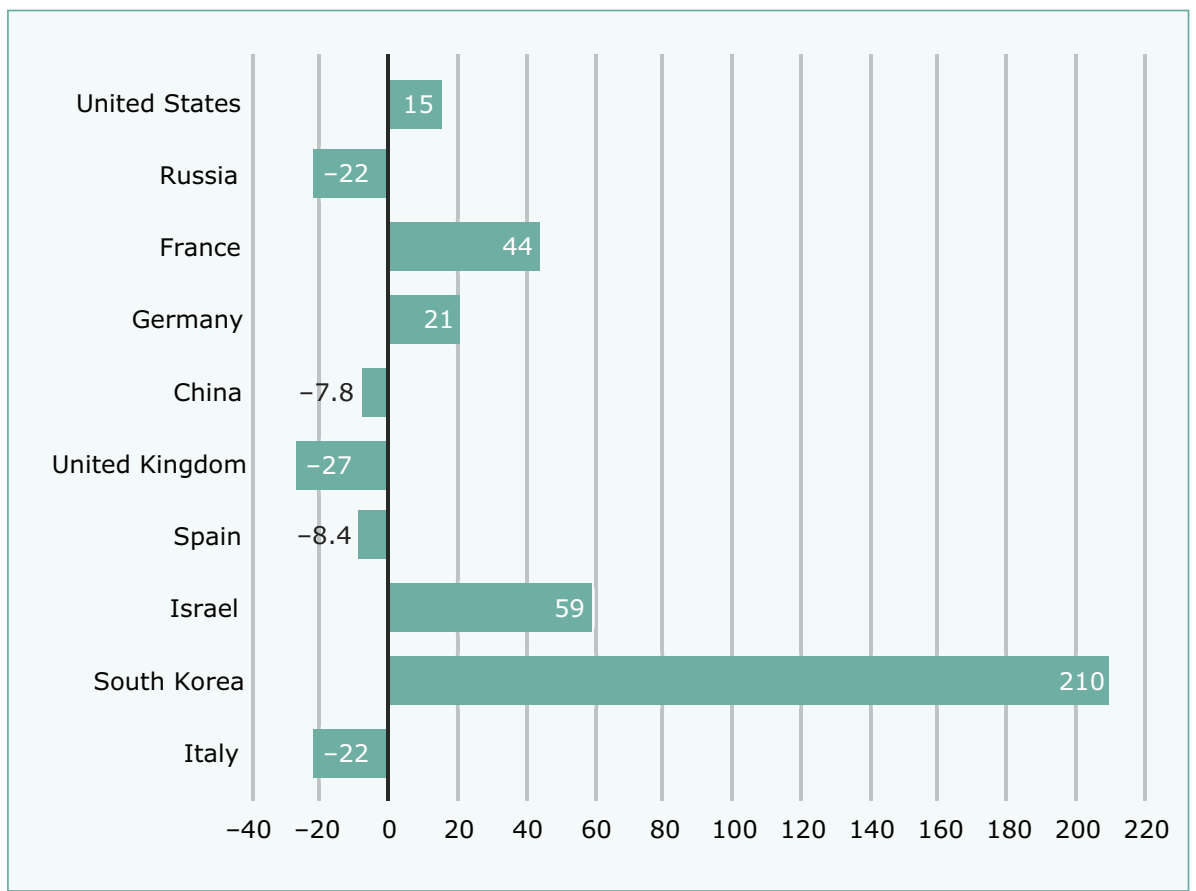

Figure 3. Changes in volume of major arms exports since 2011-15 by the 10 largest exporters in 2016-20

Source: SIPRI Arms Transfers Database, Mar. 2021. made up 46 per cent of total German arms exports in 2016-20, while deliveries of armoured vehicles accounted for 15 per cent.

The UK was the world's sixth largest arms exporter in 2016-20 and accounted for 3.3 per cent of total arms exports. British arms exports fell by 27 per cent compared with 2011-15, when they peaked due to deliveries of combat aircraft to Saudi Arabia. The UK exported arms to 39 countries in 2016-20 with its main recipient, Saudi Arabia, receiving 32 per cent of its arms exports in that period.

\section{Other top 10 suppliers}

There were three states outside Europe and North America among the top 10 arms exporters in 2016-20: China, Israel and South Korea.

China was the world's fifth largest arms exporter in 2016-20 and accounted for 5.2 per cent of total arms exports. After an increase of 77 per cent between 2006-10 and 2011-15, Chinese arms exports decreased by 7.8 per cent between 2011-15 and 2016-20.

China delivered major arms to 51 states in 2016-20. States in Asia and Oceania (76 per cent) and Africa (16 per cent) received most of China's arms exports in the period. Pakistan remained the main recipient of Chinese arms and accounted for 38 per cent of Chinese arms exports in 2016-20. In 2016-20 China continued to make efforts to develop its arms exports to the Middle East. While some arms importers in other regions do not import Chinese arms for political reasons, Middle Eastern states, several of which are among the world's largest arms importers, appear less likely to impose such restrictions. However, China's efforts to increase its arms sales to the Middle East seem to have had only a limited effect: the region accounted 
Table 2. The 40 largest importers of major arms and their main suppliers, 2016-20

Note: Percentages below 10 are rounded to 1 decimal place; percentages over 10 are rounded to whole numbers.

\begin{tabular}{|c|c|c|c|c|c|c|c|}
\hline & \multirow[b]{2}{*}{ Importer } & \multicolumn{2}{|c|}{$\begin{array}{l}\text { Share of } \\
\text { arms imports (\%) }\end{array}$} & \multirow{2}{*}{$\begin{array}{l}\text { Per cent } \\
\text { change from } \\
2011-15 \text { to } \\
2016-20^{a}\end{array}$} & \multicolumn{3}{|c|}{ Main suppliers (share of importer's total imports, \%), 2016-20 } \\
\hline & & $2016-20$ & $2011-15$ & & 1 st & 2nd & $3 \mathrm{rd}$ \\
\hline 1 & Saudi Arabia & 11 & 7.1 & 61 & USA (79) & $\mathrm{UK}(9.3)$ & France $(4.0)$ \\
\hline 2 & India & 9.5 & 14 & -33 & Russia (49) & France (18) & Israel (13) \\
\hline 3 & Egypt & 5.8 & 2.4 & 136 & Russia (41) & France (28) & USA (8.7) \\
\hline 4 & Australia & 5.1 & 3.6 & 41 & USA (69) & Spain (21) & Switzerland (3.4) \\
\hline 5 & China & 4.7 & 4.4 & 5.5 & Russia (77) & France (9.7) & Ukraine (6.3) \\
\hline 6 & Algeria & 4.3 & 2.6 & 64 & Russia (69) & Germany (12) & China (9.9) \\
\hline 7 & South Korea & 4.3 & 2.7 & 57 & USA (58) & Germany (31) & Spain (6.5) \\
\hline 8 & Qatar & 3.8 & 0.8 & 361 & USA (47) & France (38) & Germany (7.5) \\
\hline 9 & UAE & 3.0 & 4.7 & -37 & USA (64) & France (10) & Russia (4.7) \\
\hline 10 & Pakistan & 2.7 & 3.4 & -23 & China (74) & Russia (6.6) & Italy (5.9) \\
\hline 11 & Iraq & 2.5 & 2.5 & -0.6 & USA (41) & Russia (34) & South Korea (12) \\
\hline 12 & Japan & 2.2 & 1.0 & 124 & USA (97) & $\mathrm{UK}(2.1)$ & Sweden (1.0) \\
\hline 13 & United States & 2.1 & 2.9 & -30 & UK (22) & Germany (14) & Netherlands (14) \\
\hline 14 & United Kingdom & 2.1 & 1.5 & 41 & USA (72) & Spain (18) & Germany (4.0) \\
\hline 15 & Israel & 1.9 & 1.2 & 65 & USA (92) & Germany (5.9) & Italy (2.3) \\
\hline 16 & Viet Nam & 1.8 & 3.0 & -41 & Russia (66) & Israel (19) & Belarus/South Korea (4.8) \\
\hline 17 & Singapore & 1.7 & 1.8 & -9.0 & USA (36) & Spain (25) & France $(17)$ \\
\hline 18 & Indonesia & 1.7 & 2.0 & -18 & USA (23) & Netherlands (19) & South Korea (17) \\
\hline 19 & Italy & 1.5 & 0.7 & 120 & USA (62) & Germany (26) & Italy (5.9) \\
\hline 20 & Turkey & 1.5 & 3.6 & -59 & USA (29) & Italy (27) & Spain (21) \\
\hline 21 & Norway & 1.3 & 0.7 & 93 & USA (79) & South Korea (12) & Italy (3.3) \\
\hline 22 & Bangladesh & 1.2 & 1.3 & -3.6 & China (71) & Russia (16) & $\mathrm{UK}(4.1)$ \\
\hline 23 & Thailand & 1.2 & 0.8 & 44 & South Korea (26) & China (22) & Ukraine (12) \\
\hline 24 & Oman & 1.2 & 1.0 & 12 & $\mathrm{UK}(47)$ & USA (14) & Turkey (12) \\
\hline 25 & Afghanistan & 1.0 & 1.3 & -24 & USA (89) & Brazil (8.2) & Belarus (1.0) \\
\hline 26 & Netherlands & 1.0 & 0.6 & 52 & USA (90) & Germany (6.8) & Italy (2.0) \\
\hline 27 & Kazakhstan & 1.0 & 0.6 & 62 & Russia (89) & Spain (3.6) & China (2.4) \\
\hline 28 & Jordan & 0.9 & 0.6 & 38 & USA (36) & Netherlands (22) & UAE (11) \\
\hline 29 & Morocco & 0.9 & 2.1 & -60 & USA (90) & France $(9.2)$ & $\mathrm{UK}(0.3)$ \\
\hline 30 & Canada & 0.8 & 1.0 & -24 & USA (48) & Australia (14) & Israel (12) \\
\hline 31 & Philippines & 0.8 & 0.2 & 229 & South Korea (42) & Indonesia (17) & USA (17) \\
\hline 32 & Azerbaijan & 0.7 & 1.6 & -56 & Israel (69) & Russia (17) & Belarus (4.8) \\
\hline 33 & Myanmar & 0.7 & 1.2 & -40 & China (48) & India (16) & Russia (15) \\
\hline 34 & Taiwan & 0.6 & 2.0 & -70 & USA (100) & - & - \\
\hline 35 & Mexico & 0.6 & 0.7 & -14 & USA (49) & Netherlands (34) & France (10) \\
\hline 36 & Poland & 0.6 & 0.6 & -12 & USA (33) & Italy (13) & South Korea (11) \\
\hline 37 & Brazil & 0.6 & 0.9 & -38 & France (23) & USA (21) & UK (20) \\
\hline 38 & Belarus & 0.5 & 0.3 & 93 & Russia (99) & China (0.5) & - \\
\hline 39 & Angola & 0.5 & 0.1 & 843 & Russia (64) & China (9.7) & Lithuania (8.1) \\
\hline 40 & Malaysia & 0.5 & 0.2 & 114 & Spain (32) & Turkey (17) & South Korea (11) \\
\hline
\end{tabular}

$\mathrm{UAE}=$ United Arab Emirates.

${ }^{a}$ Figures show the change in volume of the total arms imports per importer between the 2 periods.

Source: SIPRI Arms Transfers Database, Mar. 2021. 
for 7.0 per cent of Chinese arms exports in 2016-20, compared with 3.8 per cent in 2011-15.

Israel was the eighth largest arms exporter in 2016-20. Its arms exports represented 3.0 per cent of the global total and were 59 per cent higher than in 2011-15. Israel delivered major arms to 40 states in 2016-20 but its main recipient, India, accounted for 43 per cent of the total. Israel's deliveries to India in 2016-20 included air defence systems.

South Korea was the ninth largest arms exporter in 2016-20 with a 2.7 per cent share of the global total. Its arms exports in 2016-20 were 210 per cent higher than in 2011-15 and 649 per cent higher than in 2001-2005. This rapid growth has mainly been

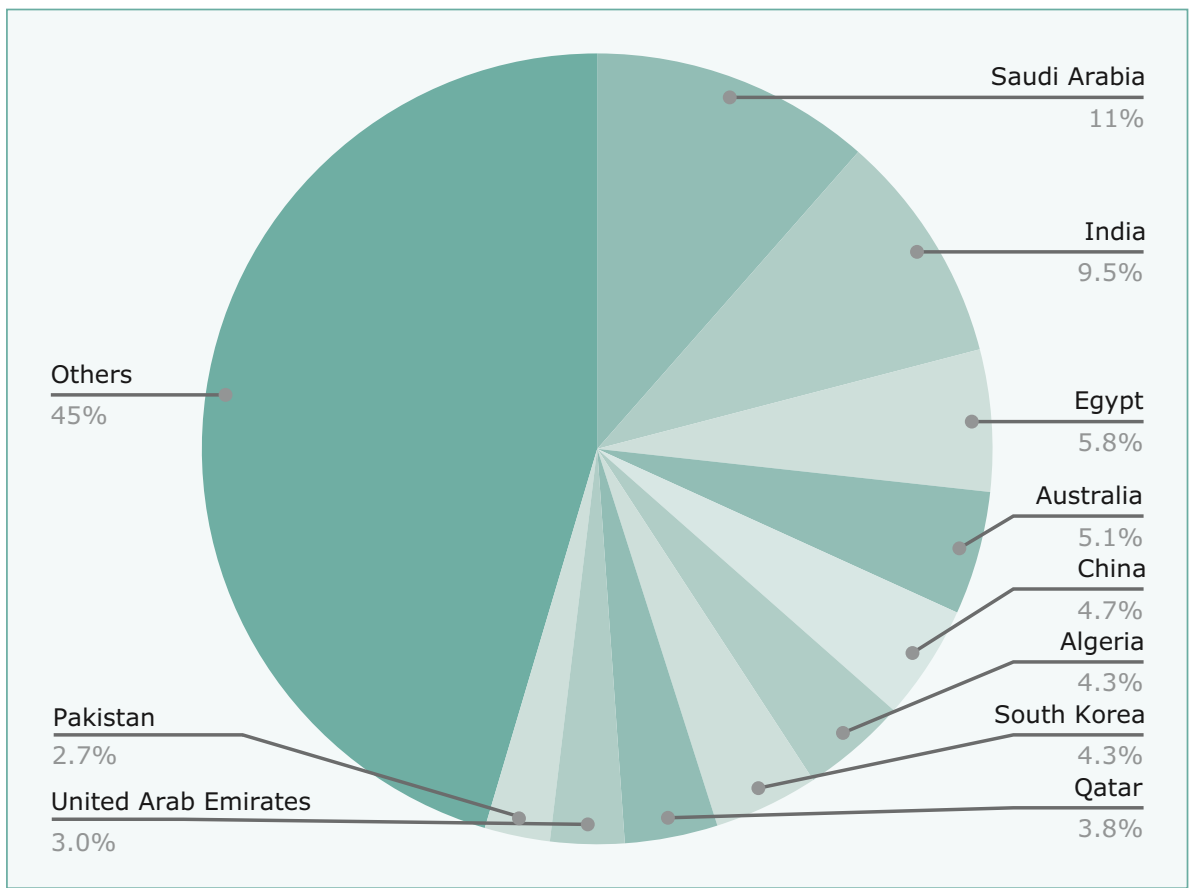

Figure 4. Global share of major arms imports by the 10 largest importers, 2016-20

Source: SIPRI Arms Transfers Database, Mar. 2021. the result of improvements in the South Korean arms industry's ability to produce advanced major arms that can compete with those produced in more established arms-supplying countries. In 2016-20 Asia and Oceania accounted for 55 per cent of South Korean arms exports, Europe for 23 per cent and the Middle East for 14 per cent.

\section{THE IMPORTERS, 2016-20}

SIPRI has identified 164 states as importers of major arms in 2016-20. The top five arms importers-Saudi Arabia, India, Egypt, Australia and China-received 36 per cent of total arms imports in 2016-20 (see figure 4 and table 2). Of these five, only Egypt was not among the top five importers in 2011-15. At the regional level, Asia and Oceania accounted for 42 per cent of arms imports in 2016-20, followed by the Middle East (33 per cent), Europe (12 per cent), Africa (7.3 per cent) and the Americas (5.4 per cent; see figure 5).

\section{Africa}

Between 2011-15 and 2016-20 imports of major arms by African states decreased by 13 per cent. In 2016-20 the three largest arms importers in Africa were Algeria (4.3 per cent of global arms imports), Morocco ( 0.9 per cent) and Angola ( 0.5 per cent).

\section{Algeria and Morocco}

Taken together, the arms imports of regional rivals Algeria and Morocco accounted for 70 per cent of total African imports of major arms in 2016-20. Algeria's arms imports were 64 per cent higher in 2016-20 than in 2011-15, 
making it the sixth largest arms importer in the world. Russia remained the largest arms supplier to Algeria in 2016-20. Russian arms deliveries included 16 combat aircraft, 42 combat helicopters and 2 submarines. Other notable deliveries to Algeria included 2 frigates from Germany and 2 frigates from China.

Arms imports by Morocco decreased by 60 per cent between 2011-15 and 2016-20. The USA supplied 90 per cent of Morocco's arms imports in 2016-20. By the end of 2020 several large arms deliveries to Morocco remained outstanding, including for 24 combat aircraft and 24 combat helicopters from the USA. Morocco's arms imports are likely to increase significantly in the coming five years if these orders are implemented as planned.

\section{Sub-Saharan Africa}

In 2016-20 sub-Saharan Africa accounted for 26 per cent of total African arms imports, compared with 41 per cent in 2011-15. Armed conflict in the Sahel coincided with increased arms imports by Burkina Faso (83 per cent) and Mali (669 per cent), both of which are members of the Joint Force of the Group of Five for the Sahel. Taken together, the deliveries to Burkina Faso and Mali in 2016-20 included a total of 322 armoured vehicles, 9 combat helicopters and several light combat aircraft. Some of these transfers were financed by the EU or were delivered as military aid by France, Qatar or the UAE.

Several major powers are using arms supplies as a foreign policy tool to increase their influence in sub-Saharan Africa. These exports are at least

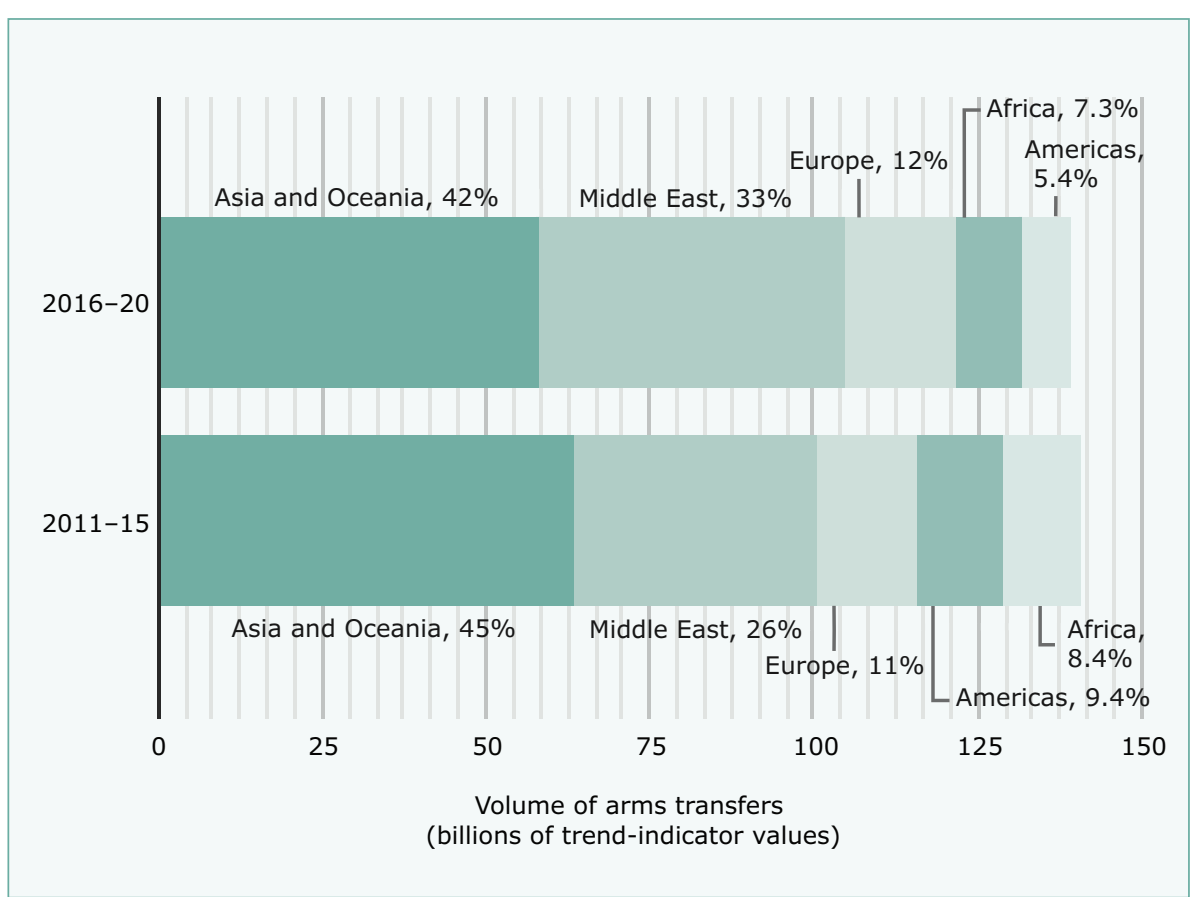

Figure 5. The importers of major arms, by region, 2016-20 and 2011-15, per cent of global share

Note: The SIPRI trend-indicator value (TIV) is a measure of the volume of international transfers of major weapons. The method used for the SIPRI TIV is described on the Arms Transfers Database web page.

Source: SIPRI Arms Transfers Database, Mar. 2021. partly driving growing arms supplier competition in the subregion. Russia was the largest arms exporter to sub-Saharan Africa in 2016-20. Its arms deliveries to 12 states represented 30 per cent of total sub-Saharan arms imports, compared with 25 per cent in 2011-15.

Twenty-one sub-Saharan states received major arms from China in 2016-20 and it accounted for 20 per cent of arms imports by states in the subregion, compared with 24 per cent in 2011-15. France's deliveries to 20 states accounted for 9.5 per cent of subSaharan arms imports, compared with 2.9 per cent in 2011-15.

Despite its military involvement in the subregion, the USA was only the fourth largest arms exporter to sub-Saharan Africa. It supplied arms to 17 states and accounted for 5.4 per cent of sub-Saharan arms imports. 


\section{The Americas}

Arms imports by states in the Americas decreased by 43 per cent between 2011-15 and 2016-20. The USA received 38 per cent of regional arms imports in 2016-20. Its imports included 92 light helicopters from Germany and a total of 89 second-hand combat aircraft for military training purposes from several states. Canada received 15 per cent of regional arms imports in 2016-20, and Mexico and Brazil each accounted for 11 per cent. While Mexico had no notable open deals for major arms at the end of 2020, Brazil's outstanding deliveries included 35 combat aircraft from Sweden, 5 submarines from France and 4 frigates from Germany.

\section{Asia and Oceania}

Arms imports by states in Asia and Oceania decreased by 8.3 per cent between 2011-15 and 2016-20. Of the 10 largest importers in 2016-20, 5 are in Asia and Oceania: India, Australia, China, South Korea and Pakistan. The USA accounted for 29 per cent of arms imports by states in the region, Russia for 27 per cent and China for 9.4 per cent.

\section{India and Pakistan}

Between 2011-15 and 2016-20 arms imports by India decreased by 33 per cent. Russia was the largest arms supplier to India in both 2011-15 and 2016-20. However, Russia's deliveries dropped by 53 per cent between the two periods and its share of total Indian arms imports fell from 70 to 49 per cent. In 2011-15 the USA was the second largest arms supplier to India, but in 2016-20 India's arms imports from the USA were 46 per cent lower than in the previous five-year period, making the USA the fourth largest supplier to India in 2016-20. France and Israel were the second and third largest arms suppliers to India in 2016-20. India's arms imports from France increased by 709 per cent while those from Israel rose by 82 per cent. Combat aircraft and associated missiles made up more than 50 per cent of Indian arms imports in 2016-20.

The overall drop in India's arms imports between 2011-15 and 2016-20 seems to be mainly due to its complex and lengthy procurement processes, combined with its attempts to reduce its dependence on Russian arms by diversifying its network of arms suppliers. As India perceives increasing threats from Pakistan and China and as its ambitious plans to produce its own major arms have been significantly delayed, it is planning large-scale programmes for arms imports. Based on its outstanding deliveries of combat aircraft, air defence systems, ships and submarines, India's arms imports are expected to increase over the coming five years.

Between 2011-15 and 2016-20 arms imports by Pakistan decreased by 23 per cent. China accounted for 61 per cent of Pakistan's arm imports in 2011-15 and for 74 per cent in 2016-20. Like India, its main regional rival, Pakistan has several large outstanding orders for arms. They are scheduled for delivery by 2028 and include 50 combat aircraft, 8 submarines and 4 frigates from China, and 4 frigates from Turkey. 
Box 2. The maritime dimension of arms transfers to the eastern Mediterranean

Several states involved in disputes over rights to maritime hydrocarbon resources in the eastern Mediterranean are strengthening their maritime capabilities through arms imports. Egypt's imports of major arms increased 136 per cent between 2011-15 and 2016-20, and it became the world's third largest arms importer. In 2016-20 it received 1 frigate, 2 amphibious assault ships and 21 combat aircraft from France; 3 submarines from Germany; 1 frigate from Italy; 50 combat aircraft and 46 ship-borne combat helicopters from Russia; and 1 corvette from South Korea. By the end of 2020, outstanding deliveries to Egypt included 1 submarine and 4 frigates from Germany, 1 frigate from Italy, 3 frigates from France, and 24 combat aircraft from Russia.

Turkey's arms imports decreased by 59 per cent between 2011-15 and 2016-20, and it dropped from being the 6th largest arms importer in the world to 20th position. This was partly because Turkey increasingly produces its own major arms, including surface ships, and partly because in 2019 the USA halted a planned delivery of combat aircraft to Turkey. Despite its growing political differences with West European arms suppliers, by the end of 2020 Turkey had outstanding deliveries for six submarines from Germany, five anti-submarine warfare aircraft from Italy and one amphibious assault ship from Spain.

Greece was the third largest arms importer in the world in 2001-2005. However, having been in the grip of an economic crisis for several years, which led to deep cuts in spending on major arms, Greece ranked 41st in 2016-20. Its largest arms import in the period was one submarine from Germany. In 2020 Greece agreed orders with France for the supply of 18 combat aircraft in 2021-23 and remained in negotiations over other large arms contracts with several states, including for more combat aircraft and several frigates.

\section{East Asia}

Arms imports by East Asian states increased by 14 per cent between 2011-15 and 2016-20. China, which received 4.7 per cent of global arms imports in 2016-20, was the largest arms importer in the subregion in both periods. The bulk of its imports comprised air defence systems, combat aircraft and engines for combat aircraft from Russia. However, imports from Russia are likely to reduce in volume once China's own industry manages to consistently produce the types of major arms that it has generally imported from Russia over the years.

Taiwan's arms imports were 70 per cent lower in 2016-20 than in 2011-15. However, its arms imports will probably increase in the coming five years based on orders signed in 2019 for 66 combat aircraft and 108 tanks from the USA. For over a decade up until 2019, the USA had been wary of agreeing to large-scale arms sales to Taiwan due to the damage previous sales had caused to US-Chinese relations. The orders in 2019 were agreed in the context of the USA's perception of China as a growing threat to its global interests and increased political pressure on Taiwan from China.

Arms imports by Japan, which also perceives China as a growing threat, increased by 124 per cent between 2011-15 and 2016-20. Japan's arms imports will probably continue to rise based on new orders for arms from the USA-including an order placed in 2019 for 105 combat aircraft. These orders are in addition to those that Japan has placed with its own arms industry.

South Korean arms imports increased by 57 per cent between 2011-15 and 2016-20. This rise was mainly driven by ongoing tensions with North Korea and can largely be attributed to the delivery of 26 combat aircraft from the USA and 5 submarines from Germany. Many arms imports by South Korea have involved technology transfers and its arms imports are therefore likely to decrease over the long term. For example, it no longer plans to import submarines, having started domestic production of a type developed by its own arms industry. 


\section{Europe}

In 2016-20 arms imports by European states were 12 per cent higher than in 2011-15. The USA accounted for 47 per cent of the region's arms imports in 2016-20, Germany for 9.7 per cent and Russia for 9.2 per cent.

\section{Armenia and Azerbaijan}

The respective arms imports of Azerbaijan and Armenia accounted for only 0.7 per cent and 0.3 per cent of global arms transfers in 2016-20. However, many of the arms delivered played a key role in the heavy fighting between the two countries in 2020. In 2016-20 a total of 94 per cent of Armenian arms imports came from Russia. These included air defence systems, combat aircraft, ballistic missiles and artillery. Azerbaijan's arms imports in 2016-20 were more than 2.5 times higher than those of Armenia. Israel accounted for 69 per cent and Russia for 17 per cent of Azerbaijan's arms imports in the period. Israeli supplies included unmanned aerial vehicles for reconnaissance, ballistic missiles and loitering munitions, while Russia supplied mainly armoured vehicles and artillery.

\section{Western and Central Europe}

Arms imports by states in Western and Central Europe rose by 22 per cent between 2011-15 and 2016-20 after a drop of 52 per cent between 2006-10 and 2011-15. The increase coincided with the economic recovery in most of Europe after the 2009 economic crisis and was in the context of heightened threat perceptions among West and Central European states relating to Russia and instability in the Middle East and North Africa (see box 2). A total of 56 per cent of arms imports by states in Western and Central Europe came from the USA in 2016-20. Deliveries of a total of 73 combat aircraft, including $71 \mathrm{~F}-35 \mathrm{~s}$, accounted for just over half of US arms exports to Western and Central Europe in the period.

\section{The Middle East}

Arms imports by states in the Middle East were 25 per cent higher in 2016-20 than in 2011-15. Four of the top 10 arms-importing states in 2016-20 are in the Middle East: Saudi Arabia, Egypt, Qatar and the UAE. The USA accounted for 52 per cent of arms imports by states in the region, while Russia supplied 13 per cent and France 12 per cent.

\section{The Gulfregion}

Against the backdrop of tense relations between several states in the Gulf region some noteworthy arms transfer developments occurred in 2016-20.

Saudi Arabia was the world's largest arms importer in 2016-20 and received 11 per cent of global arms imports. The USA accounted for 79 per cent of Saudi Arabian arms imports in 2016-20, followed by the UK with 9.3 per cent. In 2016-20 Saudi Arabia strengthened its long-range strike capabilities with 91 combat aircraft from the USA and 15 from the UK. It also imported 14 air defence systems from the USA. By the end of 2020 several large deliveries of major arms were outstanding, including for 61 combat aircraft, 4 frigates and 7 anti-ballistic missile systems from the USA, and 
SIPRI is an independent international institute dedicated to research into conflict, armaments, arms control and disarmament. Established in 1966, SIPRI provides data, analysis and recommendations, based on open sources, to policymakers, researchers, media and the interested public.

\section{GOVERNING BOARD}

Ambassador Jan Eliasson, Chair (Sweden)

Dr Vladimir Baranovsky (Russia)

Espen Barth Eide (Norway)

Jean-Marie Guéhenno (France)

Ambassador Ramtane

Lamamra (Algeria)

Dr Radha Kumar (India)

Dr Patricia Lewis (Ireland/

United Kingdom)

Dr Jessica Tuchman Mathews

(United States)

\section{DIRECTOR}

Dan Smith (United Kingdom)
5 frigates from Spain. Saudi Arabia is therefore expected to remain among the world's largest arms importers in the coming five years.

With the aim of increasing its influence in the Middle East, Qatar has vastly expanded its armed forces since around 2013. This process continued in 2016-20 and Qatari arms imports were 361 per cent higher than the previous five-year period. The increase can mainly be attributed to the delivery of 24 combat aircraft from France and 10 air defence systems from the USA.

The UAE has been among the world's top 10 arms importers for each consecutive five-year period since 2001-2005. The UAE's arms imports in 2016-20 were 37 per cent lower than in 2011-15, when they peaked. Outstanding deliveries at the end of 2020-including for 2 frigates from France as well as air defence systems and 38 combat helicopters from the USA-indicate that the UAE's arms imports will continue to be at a high level in the coming years. After the normalization of relations between the UAE and Israel in 2020, the USA agreed to sell 50 F-35 combat aircraft to the UAE. If deliveries of these aircraft are implemented as planned, the UAE's arms imports will increase in the second half of the 2020s.

In 2016-20 Iran's arms imports represented 0.3 per cent of the global total. In 2020 the United Nations lifted its 2010 embargo on exports of most types of major arms to Iran. Although this led to speculation that Iran would immediately begin to order large volumes of arms, as of the end of 2020, no new Iranian contracts for major arms had been identified by SIPRI.

\begin{abstract}
About SIPRI's data on arms transfers
SIPRI's statistical data on arms transfers relates to actual deliveries of major arms, as defined by SIPRI. SIPRI measures the volume of international transfers of major arms using a common unit-the trend-indicator value (TIV). The method used for the SIPRI TIV is described on the Arms Transfers Database web page.

As the volume of deliveries can fluctuate significantly year-on-year, SIPRI presents data for five-year periods, giving a more stable measure of trends. Percentage shares presented in this Fact Sheet do not always add up to 100 per cent or to stated totals because of the conventions of rounding.

The SIPRI Arms Transfers Database, accessible on the SIPRI website, is the only public resource that provides consistent information, often estimates, on all international transfers of major arms (including sales, gifts and production under licence) to states, international organizations and non-state groups since 1950. The database aims to contribute to an understanding of the effects of arms flows on peace, stability and violent conflict. This Fact Sheet is intended to encourage the use of the database for further research, investigations, policymaking and public debate.
\end{abstract}

\section{ABOUT THE AUTHORS}

Pieter D. Wezeman (Netherlands/Sweden) is a Senior Researcher with the SIPRI Arms and Military Expenditure Programme. Alexandra Kuimova (Russia) is a Researcher and Siemon T. Wezeman (Netherlands) is a Senior Researcher with the programme.
STOCKHOLM INTERNATIONAL PEACE RESEARCH INSTITUTE Signalistgatan 9 SE-169 72 Solna, Sweden Telephone: +4686559700 Email:sipri@sipri.org Internet: www.sipri.org 